\title{
Frequência de anticorpos e fatores de risco para a infecção pelo vírus da diarreia viral bovina em fêmeas bovinas leiteiras não vacinadas na região amazônica maranhense, Brasil
}

\author{
Frequency of antibodies and risk factors of bovine viral diarrhea virus infection in \\ non-vaccinated dairy cows in the Maranhense Amazon region, Brazilfonte 10
}

\author{
Nancyleni Pinto Chaves ${ }^{\mathrm{I}}$ Danilo Cutrim Bezerra $^{\mathrm{I}}$ Vanessa Evangelista de Sousa ${ }^{\mathrm{II}}$ \\ Hamilton Pereira Santos ${ }^{\mathrm{III}}$ Hélder de Moraes Pereira ${ }^{\mathrm{IV}}$
}

\section{- NOTA -}

\section{RESUMO}

O presente estudo teve como objetivo determinar a frequência e os fatores de risco para a infecção pelo vírus da diarreia viral bovina (BVDV) em fêmeas bovinas leiteiras na região amazônica maranhense. Amostras de soro de animais não vacinados contra o BVDV e provenientes de 40 propriedades foram submetidas à técnica de ELISA indireto. Em cada propriedade avaliada, aplicou-se ainda um questionário epidemiológico para investigar os fatores de risco que poderiam estar associados à infecção pelo vírus. As amostras foram coletadas de animais que apresentavam ou não sinais clínicos sugestivos da infecção pelo BVDV. Das 400 amostras de soro analisadas, $61,5 \%(n=246)$ foram reagentes com a deteç̧ão de bovinos sorologicamente positivos em $95 \%$ $(n=38)$ das propriedades. Dentre os fatores de risco avaliados, produção de leite (1-5L), ausência de assistência veterinária, uso de monta natural e monta natural associada à inseminação artificial apresentaram significância estatística $(P<0,05)$ associada à infecção pelo BVDV. Os resultados do estudo indicam que a frequência de anticorpos contra o BVDV foi elevada na região amazônica maranhense e que os fatores relacionados às características das propriedades e ao manejo foram associados ao risco de infecção pelo BVDV.

Palavras-chave: BVDV, anticorpos, ELISA, vacas leiteiras, fatores de risco.

\section{ABSTRACT}

This study was performed in order to determine the frequency of bovine viral diarrhea virus (BVDV), and the main factors related to the frequency of the infection in dairy cows not vaccinated against BVDV from Maranhense Amazon region. Serum samples were submitted to an indirect ELISA test for detection of BVDV antibodies. An epidemiological questionnaire was applied for each herd to investigate variables that could beassociated with this infection. Serum samples were collected from 40 farms, with or without clinical signs of BVDV infection. From 400 serum samples examined, 61.5\% $(n=246)$ in $95 \%(n=38)$ of the herds were positive for ELISA. Variables identified as risk factors such as milk production (1-5L), absence of veterinary assistance, use of natural breeding or natural breeding associated with artificial insemination. These risk factors presented statistical significance $(P<0.05)$ associated to $B V D V$ infection. These results indicate that $B V D V$ infection is high in the studied region and that factors related to the herd characteristic and management were associated with the risk of infection by BVDV.

Key words: BVDV, antibodies, ELISA, dairy cows, risk factors.

O vírus da diarreia viral bovina (BVDV) é um dos patógenos mais importantes de bovinos e responsável por grandes perdas econômicas para a pecuária bovina em todo mundo. Além de infecções subclínicas, o BVDV pode causar sintomatologias respiratória, digestiva, reprodutiva, doença das mucosas (DM), síndrome hemorrágica $(\mathrm{SH})$ e imunodepressão. As maiores perdas resultam da infecção de fêmeas prenhes, podendo ocorrer reabsorção embrionária, abortamentos, mumificações,

'Universidade Estadual do Maranhão (UEMA), 65055-970, São Luís, MA, Brasil. E-mail: nancyleni@hotmail.com. *Autor para correspondência.

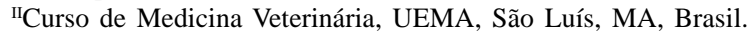

"IDepartamento de Patologia, UEMA, São Luís, MA, Brasil.

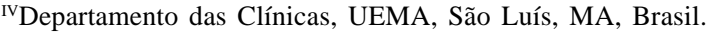


natimortalidade, malformações fetais, nascimento de bezerros fracos, persistentemente infectados (PI) e imunotolerantes ao vírus (DIAS \& SAMARA, 2003).

A infecção pelo BVDV está amplamente difundida no rebanho bovino brasileiro. O vírus já foi isolado nas regiões Sudeste, Centro-oeste e Sul e exames sorológicos realizados em alguns estados comprovam que o vírus está disseminado na população bovina do país (FLORES et al., 2000).

O diagnóstico da Diarreia Viral Bovina (BVD) é realizado por meio da detecção do vírus (ou antígenos virais) e da demonstração de anticorpos específicos. O isolamento do vírus em cultivo celular confirma a presença desse agente nos animais infectados. A identificação final do vírus pode ser realizada também por diferentes técnicas sorológicas, como soroneutralização, imunofluorescência, imunoperoxidase e ensaio imunoenzimático (ELISA) (PILZ et al., 2005).

O presente trabalho teve como objetivo determinar a frequência de anticorpos e fatores de risco associados à infecção pelo BVDV na região amazônica maranhense. O estudo foi realizado na região amazônica maranhense, abrangendo as terras maranhenses a oeste do meridiano de $44^{\circ}$. A área de estudo compreendeu as regionais de Açailândia e Imperatriz, totalizando $22.700 \mathrm{~km}^{2}$ de região amazônica maranhense.

Foram coletadas 400 amostras de soro de animais, em 40 propriedades da região amazônica maranhense. Dessas propriedades, 12 foram da regional de Açailândia e 28 da regional de Imperatriz. Para se estabelecer o tamanho da amostra, foi adotada, como valor de referência, a prevalência observada por CASTRO et al. (1993), que foi de 70\% no Estado do Pernambuco, sendo considerados uma margem de erro (e) de 3\% e um nível de confiança (Z) de 95\%.

Para o presente estudo, foram utilizadas apenas fêmeas bovinas leiteiras não vacinadas contra o BVDV e estratificadas em três faixas etárias: < três anos (estrato-I), entre três a sete anos (estrato-II) e acima de sete anos (estrato-III), apresentando ou não sinais clínicos sugestivos da infecção pelo BVDV.

O sangue foi coletado por punção da veia jugular, com agulhas descartáveis e sistema de vácuo. O soro foi separado do sangue total por centrifugação a $250 \mathrm{x}$ g, durante $15 \mathrm{~min}$ e acondicionado em microtubos e posteriormente foi estocado à temperatura de $-20^{\circ} \mathrm{C}$ até a realização do teste. A detecção qualitativa de anticorpos anti-BVDV foi realizada mediante a técnica de ELISA, utilizando o Kit comercial de ELISA indireto (CHEKITBVD-SERO-Dr. BOMMELIAG / Liebefeld - Bern - Swiss), de acordo com as instruções do fabricante.
Para cada propriedade estudada, foi aplicado questionário epidemiológico para obtenção de informações referentes às propriedades, aos animais estudados e ao manejo. As seguintes variáveis foram analisadas no questionário: tipo de ordenha, reposição dos animais, produção de leite por vaca, assistência veterinária, reprodução e abortamentos. Para o estudo da associação entre a soropositividade e as variáveis analisadas, foi utilizado teste Exato de Fisher ou, teste Qui-quadrado de independência, quando as condições para o teste Exato de Fischer não foram verificadas. O nível de significância utilizado foi de 5\%, com intervalos de confiabilidade de 95\%.

O estudo sorológico revelou que $61,5 \%$ $(n=246)$ das amostras apresentaram anticorpos contra o BVDV. Esse valor está de acordo com as estimativas de prevalência de anticorpos contra BVDV na população bovina, que varia de 50 a 90\% (HOUE, 1999).

Nas regionais estudadas, Açailândia obteve frequência de $80 \%$ (n=96) e Imperatriz 53,5\% ( $n=150)$ de animais reagentes. Das 40 propriedades amostradas, $95 \%(n=38)$ apresentaram pelo menos um animal reagente ao BVDV. Os resultados do presente estudo indicam que a infecção está amplamente distribuída na região estudada.

Quanto à faixa etária, foi encontrada maior frequência para o estrato-II (três a sete anos), com 37,2\% ( $n=139)$ de reagentes. As faixas etárias, < três anos e > sete anos evidenciaram frequências de 9,5 e 15\%, respectivamente. Situação semelhante foi observada por CASTRO et al. (1993), no Estado de Pernambuco, e esses resultados podem ser explicados pelo fato de que, quanto maior a idade do animal, maiores são as chances de ele se expor ao agente. Além disso, os animais na idade adulta estão no pico de atividade produtiva e reprodutiva, tornando-os susceptíveis a enfermidades de etiologias diversas.

As variáveis analisadas no questionário como prováveis fatores de risco associados à infecção pelo BVDV nas propriedades podem ser observadas na tabela 1. A variável produção de leite/vaca mostrou maior frequência de animais reagentes nas propriedades com produção de um a cinco litros de leite (40,5\%), com associação significativa dessa variável ao risco de infecção pelo BVDV $(\mathrm{P}<0,05)$.

Infecções que causam distúrbios reprodutivos, de modo geral, podem apresentar redução na produção de leite. Segundo BENNETT et al. (1999), há uma associação negativa entre vacas não vacinadas infectadas pelo vírus e produtividade desses animais, ou seja, a produção de leite nesses rebanhos pode sofrer queda de até $30 \%$. 
Tabela 1 - Fatores de risco para o vírus da diarreia viral bovina (BVDV) em fêmeas bovinas leiteiras na região amazônica maranhense.

\begin{tabular}{|c|c|c|c|c|c|c|c|c|c|c|}
\hline & & ----- & ------Dia & eia Vira & Bovina & 3VD)--- & --------- & & & \\
\hline \multicolumn{2}{|c|}{ Variáveis } & \multicolumn{2}{|c|}{ Reagentes } & \multicolumn{2}{|c|}{ Não reagentes } & \multicolumn{2}{|c|}{ Total } & \multirow[t]{2}{*}{ OR } & \multirow[t]{2}{*}{ IC 95\% } & \multirow[t]{2}{*}{ Valor de $\mathrm{P}$} \\
\hline & & $\mathrm{N}$ & $\%$ & $\mathrm{~N}$ & $\%$ & $\mathrm{~N}$ & $\%$ & & & \\
\hline \multirow{2}{*}{ Tipo de ordenha } & Manual & 238 & 59,5 & 133 & 28,2 & 371 & 87,7 & \multirow{2}{*}{0,22} & \multirow{2}{*}{$0,02-1,80$} & \multirow{2}{*}{0,16} \\
\hline & Mecânica & 8 & 2,0 & 1 & 0,2 & 9 & 2,2 & & & \\
\hline \multirow{3}{*}{ Reposição de animais } & Região & 232 & 58,0 & 130 & 32,5 & 362 & 90,5 & \multirow{3}{*}{---} & \multirow{3}{*}{---} & \multirow{3}{*}{0,68} \\
\hline & Estado & 64 & 16,0 & 43 & 10,7 & 107 & 26,7 & & & \\
\hline & Outros Estados & 36 & 9,0 & 19 & 4,75 & 55 & 13,75 & & & \\
\hline \multirow{2}{*}{ Produção de leite/vaca } & $1-5 \mathrm{~L}$ & 162 & 40,5 & 103 & 25,7 & 265 & 66,2 & \multirow{2}{*}{0,58} & \multirow{2}{*}{$\begin{array}{c}0,35- \\
0,93\end{array}$} & \multirow{2}{*}{$0,02 * a$} \\
\hline & $6-10 \mathrm{~L}$ & 84 & 21,0 & 31 & 7,7 & 115 & 28,7 & & & \\
\hline \multirow{2}{*}{ Assistência veterinária } & Sim & 21 & 5,2 & 28 & 7,0 & 49 & 12,2 & \multirow{2}{*}{0,35} & \multirow{2}{*}{$\begin{array}{c}0,19- \\
0,65\end{array}$} & \multirow{2}{*}{$0,00 * \mathrm{a}$} \\
\hline & Não & 225 & 56,2 & 106 & 26,5 & 331 & 82,7 & & & \\
\hline \multirow{3}{*}{ Reprodução } & $\mathrm{MN}$ & 204 & 51,0 & 98 & 24,5 & 302 & 75,5 & \multirow{3}{*}{---} & \multirow{3}{*}{---} & \multirow{3}{*}{$0,00 * b$} \\
\hline & IA & 34 & 8,5 & 25 & 6,2 & 59 & 14,7 & & & \\
\hline & $\mathrm{MN}+\mathrm{IA}$ & 8 & 2,0 & 11 & 2,7 & 19 & 4,7 & & & \\
\hline \multirow[b]{2}{*}{ Abortamento } & Sim & 246 & 61,5 & 134 & 33,5 & 380 & 95,0 & \multirow[b]{2}{*}{---} & \multirow[b]{2}{*}{--- } & \multirow[b]{2}{*}{--} \\
\hline & Não & --- & --- & --- & --- & --- & --- & & & \\
\hline
\end{tabular}

OR - Odds Ratio; IC - intervalo de confiança; MN - Monta natural; IA - Inseminação artificial; (*) Associação significativa em nível de 5\%; (a) Teste exato de Fischer; (b) Teste de Qui-quadrado.

Em relação à variável assistência veterinária, foram observadas frequências mais elevadas $(56,2 \%)$ nos animais procedentes das propriedades que não utilizavam assistência técnica quando comparadas àquelas que a utilizavam $(5,2 \%)$. Essa variável apresentou associação estatística significativa para a ocorrência da infecção. A falta de assistência veterinária pode ter refletido especialmente na ausência de diagnóstico e na de implantação de programas de controle para a BVD.

Propriedades que utilizavam somente monta natural (MN) como forma de reprodução tiveram o touro como fator de risco para a infecção pelo BVDV $(\mathrm{P}<0,05)$, o que é corroborado pelo estudo de FRAY et al. (2000), ao observarem que o sêmen de reprodutores cursando a forma aguda da doença pode se tornar fonte transitória de infecção. Isso também ocorreu em propriedades que associavam monta natural com a inseminação artificial (IA).

Os maiores problemas causados pelo BVDV estão relacionados à esfera reprodutiva (FLORES, 1997). Assim, o comprometimento do desempenho reprodutivo, principalmente quanto à ocorrência de aborto, foi detectado em $100 \%$ das propriedades.
A alta frequência de anticorpos anti-BVD é um alerta para a implementação de medidas visando à prevenção e ao controle da infecção na região estudada. A prevenção de novas infecções pode ser realizada utilizando-se uma combinação entre a remoção gradual dos animais infectados e a eliminação dos animais PI, juntamente com a realização de quarentena no ingresso de bovinos na propriedade e exames sorológicos anuais, buscando impedir a reintrodução de animais infectados no rebanho (DIAS \& SAMARA, 2003).

Para a prevenção e o controle da BVD, também pode se fazer uso de vacinas; entretanto, a eficácia das vacinas comerciais inativadas é limitada, pois induzem títulos baixos a moderados de anticorpos neutralizantes e, principalmente, não conferem proteção fetal. Além disso, existe o agravante de algumas cepas isoladas no Brasil serem pouco neutralizadas pelos anticorpos contra cepas de referência internacional usadas nas vacinas comerciais (BOTTON et al., 1998).

Em resumo, os resultados do estudo indicam uma elevada frequência de anticorpos contra o BVDV em fêmeas bovinas não vacinadas da região amazônica maranhense. Além disso, os fatores de risco associados 
à infecção pelo vírus foram: menor produção de leite/ vaca, ausência de assistência médico-veterinária e presença de falhas reprodutivas no rebanho.

\section{AGRADECIMENTO}

Ao Instituto de Agronegócios do Maranhão (INAGRO), em nome do Dr. Ataíde, pelo suporte financeiro necessário para realização deste trabalho.

\section{REFERÊNCIAS}

BENNETT, R.M. et al. Modeling the impact of livestock disease on production: case studies on non-notifiable diseases on farm animals in Great Britain. Animal Science, v.68, p.681-689, 1999.

BOTTON S.A. et al. Caracterização preliminar de amostras do vírus da diarréia viral bovina (BVDV) isoladas no Brasil. Pesquisa Veterinária Brasileira, v.18, p.84-92, 1998. Disponível em: <http://www.scielo.br/pdf/pvb/v18n2/0899.pdf> . Acesso em: 10 nov. 2009.

CASTRO, R.S. et al. Anticorpos neutralizantes contra pestivirus em soros bovinos do estado do Pernambuco. Pesquisa Agropecuária Brasileira, v.28, n.11, p. 1327-1331, 1993.

DIAS, F.C.; SAMARA, S.I. Deteç̧ão de anticorpos contra o vírus da diarréia viral bovina no soro sangüíneo, no leite individual e no leite de conjunto em tanque de expansão de rebanhos não vacinados. Brazilian Journal Veterinary Research and Animal Science, v.40, p.161-168, 2003. Disponível em: <http://www.scielo.br/pdf/bjvras/v40n3/ v40n3a01.pdf>. Acesso em: 30 out. 2009.

FLORES, E.F. Problemas reprodutivos em bovinos causados pelo vírus da diarréia viral bovina (BVDV). Revista Brasileira de Reprodução Animal, v. 21, n.3, p.57-61, 1997.

FLORES, E.F. et al. Diversidade antigênica de amostras do vírus da diarréia viral bovina isoladas no Brasil: implicações para o diagnóstico e estratégias de imunização. Arquivo Brasileiro de Medicina Veterinária e Zootecnia, v.52, n.1, p.11-17, 2000. Disponível em: <http://www.scielo.br/ scielo.php? script =sci_arttext\&pid=S010209352000000100003>. Acesso em: 14 nov. 2009. doi: 10.1590/S0102-09352000000100003.

FRAY, M.D. et al. The effects of bovine viral diarrhoea virus on cattle reproduction in relation to disease control. Animal Reproduction Science, v.60, p.615-627, 2000.

HOUE, H. Epidemiological features and economical importance of bovine viral diarrhea virus (BVDV) infections. Veterinary Microbiology, v.64, p.89-107, 1999.

PILZ, D. et al. Comparação de diferentes protocolos para detecção do vírus da diarréia viral bovina por RT-PCR em grupos de sangue total e de soro sangüíneo, artificialmente contaminados. Ciências Agrárias, v.26, n.2, p.219-228, 2005. Disponível em: <http://www.uel.br/revistas/uel/index.php/ semagrarias/article/view/2295/1975>. Acesso em: 01 nov. 2009. 